\title{
Pengembangan Estetika Melalui Kegiatan Cooking Class di RA As-Shofa Ciparay
}

\author{
Heri Hidayat, Nadia Nuraziani, Qolbiatum Mutmainah, Silva Inten Sulistya \\ UIN Sunan Gunung Djati Bandung, Bandung, Indonesia
}

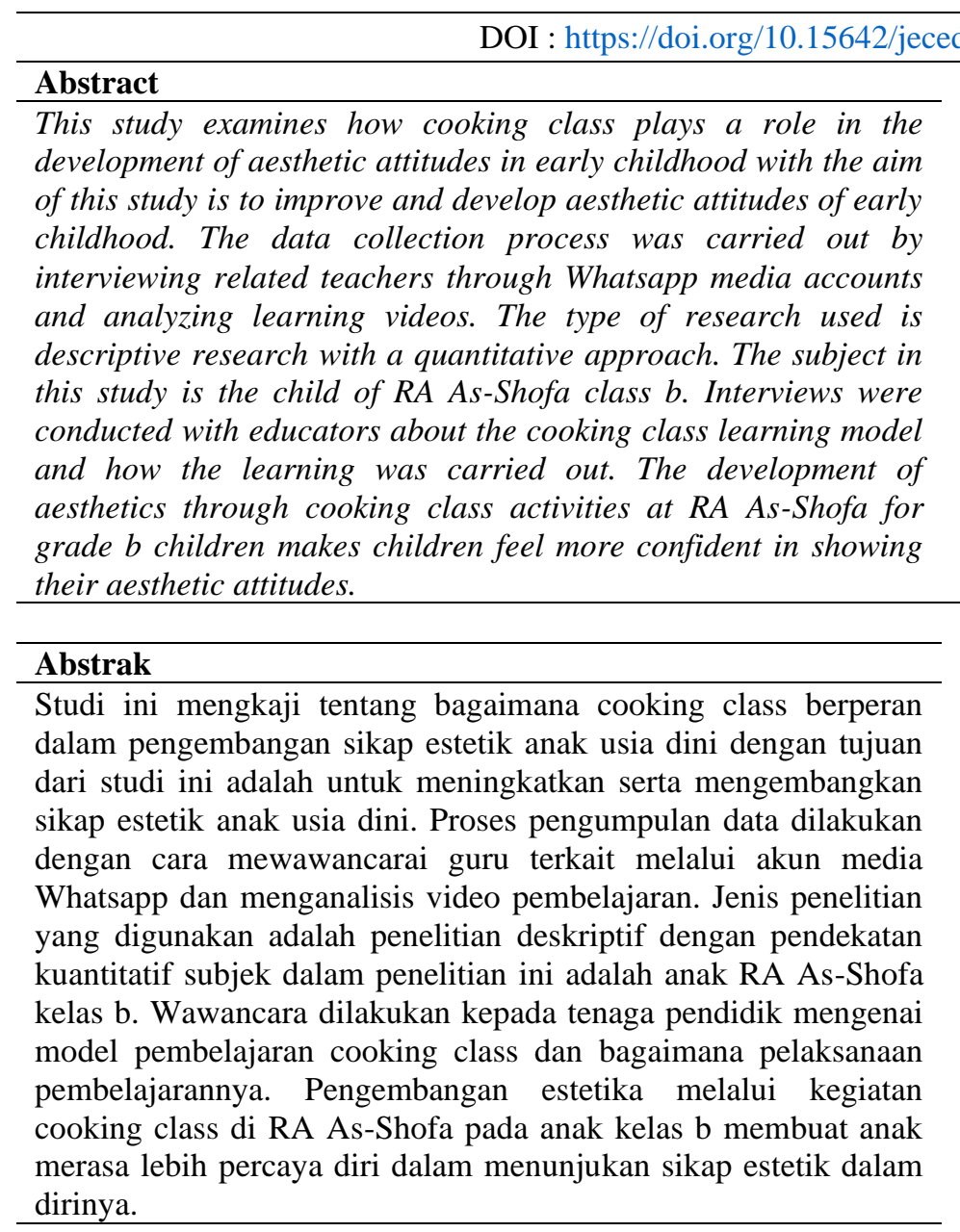

\begin{tabular}{l}
\hline Informasi Artikel \\
\hline Riwayat Artikel \\
Diterima: 23122020 \\
Disetujui: 30062021 \\
Publikasi online: 30062021 \\
\hline
\end{tabular}

Article Info

Article history:

Received: December 23, 2020

Approved: June 30, 2021

Published online: June 30, 2021

\section{Keywords:}

Aesthetics,

Cooking Class,

Early childhood

\section{Kata kunci:}

Estetika,

Cooking Class,

anak usia dini

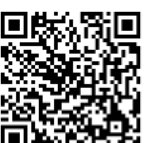




\section{PENDAHULUAN}

Pendidikan Anak Usia Dini merupakan bagian dari Ilmu Pendidikan yang secara spesifik mempelajari pendidikan anak usia 0-8 tahun (Suyanto, 2005). Adapun menurut Undang-undang Nomor 20 Tahun 2003 tentang Sistem Pendidikan Nasional Pasal 1 angka 14 menyatakan bahwa Pendidikan Anak Usia Dini (PAUD) adalah suatu upaya pembinaan yang ditujukan kepada anak sejak lahir sampai dengan usia enam tahun yang dilakukan melalui pemberian rangsangan pendidikan untuk membantu pertumbuhan dan perkembangan jasmani dan rohani agar anak memiliki kesiapan dalam memasuki pendidikan lebih lanjut (permendiknas No. 58, 2009).

Berdasarkan UU no. 20 di atas dapat diketahui bahwa pendidikan dapat di berikan sejak anak usia 0 tahun melalui pemberian rangsangan pendidikan yang tepat, sehingga berbagai potensi yang dimiliki dapat berkembang optimal. Usia 0-6 tahun atau yang disebut juga masa kanak - kanak adalah waktu yang ideal untuk mempelajari ketrampilan berbagai aspek yang berkembang pada masa tertentu. Dalam hal ini Hurlock memberikan alasan, yaitu pertama anak-anak. senang mengulang-ulang, sehingga mereka cepat terampil. Kedua Anak-anak mudah dan cepat belajar karena tubuh mereka masih lentur, sehingga dapat dibentuk dengan baik (Kamtini dan Husni, 2005 :1).

Dalam (Falah, 2019) dikemukakan nilai-nilai estetika dalam penataan lingkungan pendidikan dan implementasinya, khusus (Placeholder1)nya dalam pendidikan anak usia dini adalah penting bagi pendidik/guru. Estetika sebagai bagian dari aksiologi, mengkaji masalah yang berkaitan dengan keindahan, bagaimana ia terbentuk, dan bagaimana seseorang akan merasakannya. Penerapan nilai-nilai estetika dalam lingkungan pendidikan pada dasarnya akan menarik minat peserta didik, sehingga merasa nyaman dalam lingkungan tersebut. Lingkungan pendidikan yang sesuai dengan kondisi psikologis peserta didik, akan menjadikan kegiatan pembelajaran berjalan kondusif. Cooking class adalah suatu kegiatan memasak yang dilakukan secara berkelompok dalam sebuah tempat untuk mengolah dan memasak dengan cara lebih terkonsep dengan benar.

Kegiatan cooking class atau kelas memasak adalah kegiatan yang sangat menarik minat anak, sangat jarang sekali anak yang tidak menyukai kegiatan ini. Melalui kegiatan ini anak dapat memperoleh berbagai pengetahuan dan pengalaman secara langsung bagai mana proses pembuatan suatu makanan sebelum disajikan. Kegiatan cooking class inipun sesuai dengan Karakteristik Kurikulum 2013 Pendidikan Anak Usia Dini seperti yang tercantum dalam PERMENDIKBUD. No 146 Tahun 2014 sebagai berikut: "Mengoptimalkan perkembangan anak yang meliputi: aspek nilai kegiatang tercermin dalam kopetensi sikap, pengetahuan dan keterampilan" (Bakhti, 2015).Tujuan dari kegiatan tersebut dalam Montolalu (2005:315) yaitu: a). Mengembangkan ekspresi melalui berbagai media dengan gerakan tangan b). Mengembangkan fantasi, imajinasi dan kreasi c). Melatih otot - otot tangan/jari, koordinasi otot dan mata d). Melatih kecakapan mengkombinasi warna e). Menunjuk perasaan terhadap gerakan tangan f). Mengembangkan motorik halus anak Kegiatan cooking class berdasarkan pendapat dari Pramita, (2010:47) merupakan wahana yang tepat untuk anak TK yang mampu menumbuhkan dan meningkatkan pengalaman belajar anak secara langsung. Pada saaat yang sama, aktivitas ini mampu membangun kreativitas anak, mengenalkan bahan makanan, mengolah makanan, perpaduan warna, bahkan melatih motorik halus anak, melalui gerakan memotong, meremas, membentuk dan mencetak. (Abdah, 2013).

Sentra memasak yang dilaksanakan sejak dini sangat bermanfaat bagi anak untuk mengembangkan seluruh potensi yang ada pada diri anak tersebut. Menurut Bartono dkk, (2006:15) menyatakan bahwa "memasak adalah membuat suatu bahan mentah menjadi 
matang dengan tujuan agar dapat dimakan sesuai dengan naluri manusia". Dengan kata lain mengolah bahan mentah menjadi matang yang siap untuk di hidangkan dengan maksud atau tujuan tertentu. Menurut Sukerti (2008:63) tujuan dari cooking class adalah belajar membuat makanan itu lebih mudah dicerna dalam perut, meningkatkan pengetahuan dan keterampilan tentang seni memasak, melatih mengolah makanan dengan berbagai teknik, dan mengetahui cara membuat makanan itu aman untuk dikonsumsi. Menurut Iskandar (2005:71) dalam teori cooking class memiliki istilah-istilah sebagai dasar dalam teknik memasak sederhana. Istilah-istilah dasar memasak juga melatih gerak tangan seseorang dalam seni memasak seperti menusuk, memotong, mememarkan, meremas dan mencincang. (Pudjawan, Juniyanasari, \& Ujianti, 2015). Peneliti tertarik dengan judul cooking class ini dikarenakan dalam kegiatannya sendiri tidak hanya pengalaman memasaknya yang didapatkan oleh anak, tetapi bagaimana membangun sikap estetik melalui suatu karya yang dapat dinikmati setiap harinya.

\section{METODE}

Metode yang ada dalam penelitian ini adalah deskriptid kualitatif. Penelitian ini dilaksanakan di RA As-Shofa Ciparay Kabupaten Bandung Pada Tahun ajaran ganjil 2020. Subjek yang ada dalam penelitian ini adalah anak usia 5-6 tahun yang berjumlah 8 orang. Penelitian ini difokuskan pada pelaksanaan kegiatan cooking class dengan yang dimaksudkan untuk meningkatkan aspek-aspek perkembangan anak di RA As-Shofa Kabupaten Bandung. Adapun Teknik data yang dilakukan adalah dengan metode wawancara melalui sosial media, observasi serta dokumentasi.

Adapun tahap penelitian yang dilakukan dimaksud untuk mengembangkan kemampuan berkreasi membuat makanan hingga memiliki nilai estetika. Analisis dari penelitian ini berbentuk komponen dan analisis tema, pembahasan dilakukan dengan mendapatkan informasi yang diperoleh dengan metode wawancara melalui media sosial yang relevan serta sumber tertulis dalam foto merupakan sumber data penelitian ini.

\section{HASIL DAN PEMBAHASAN}

\section{Deskripsi Hasil Pembelajaran}

Membuat Roti Isi. Kegiatan dilakukan pada hari kamis tanggal 15 Oktober 2020. Melalui apa yang peneliti observasi bertempat di RA As-Shofa Ciparay Kabupaten Bandung dengan metode wawancara melalui media sosial yaitu Whatsapp. Kegiatan diawali dengan pembukaan yang disesuaikan dengan SOP, sebelum memasuki kelas guru membantu siswa untuk mencuci tangan terlebih dahulu serta menggunakan handsanitizer. Selanjutnya anak diarahkan untuk merentangkan tangannya sehingga dapat duduk berjarak kemudian berdoa.

Guru pendamping mempersiapkan bahan serta alat yang digunakan untuk dapat memulai kegiatan cooking class. Guru memulai pembelajaran dengan menanyakan terlebih dahulu perasaan anak hari ini "bagaimana perasaan anak hari ini? Senang bisa bertemu lagi dengan teman-teman" setelah bercakap-cakap dengan anak, kemudian guru mendeskripsikan kegiatan yang akan dilaksanakan hari itu disertai dengan pertanyaan contohnya "hari ini kita akan membuat roti isi, ada yang tahu bagaimana roti isi itu?". Lalu ada satu orang anak yang menjawab "aku suka roti isi bu guru, biasanya mamah aku buat kalo aku mau berangkat sekolah isinya suka ada selai stroberi sama ceres".

Kemudian guru menjelaskan kembali apa saja bahan yang digunakan untuk membuat roti isi "ada roti tawar, ada buah pisang, ada selai stroberi dan coklat". Setelahnya guru membagikan masing-maisng anak bahan-bahan membuat roti isi serta piring kertas untuk alas roti. Anak diinstruksikan untuk mengupas serta memotong buah 
pisang menjadi beberapa bagian dengan menggunakan alat yaitu pisau plastik. Setelah itu guru memberikan arahan kepada anak untuk mengoleskan selai yang anak gemari pada roti tawar. Tidak sedikit anak yang mengoleskan dua selai sekaligus, ada juga yang mengoleskan satu sisi selai stroberi dan pada satu sisinya lagi selai coklat, ketika itu guru bertanya "kenapa ya, ini sebelah-sebelah selainya?" lalu anak pun menjawab "biar bagus bu guru, roti isi aku gak sama dengan orang lain jadi kaya bendera Indonesia".

Usai menebarkan selai di roti, kemudian guru menginterupsi kreativitas siswa untuk berkreasi dengan irisan pisang, guru memberikan contoh pembuatan cacing dari susunan irisan pisang. Guru bertanya "nah anak-anak boleh bikin roti isi bentuknya apa saja, Kalau mau bentuk ayam, boleh" biarkan anak menyerukan bentuk yang mereka inginkan. Guru mendekati anak satu per satu untuk melihat betapa kreatifnya mereka. Ada anak yang sedang membuat wajah kucing, ada juga yang membentuk kereta api dan berbagai macam kreasi yang dibuat anak. Di akhir pelajaran, guru menginstruksikan kepada anakanak untuk menceritakan apa yang mereka buat lalu anak yang membuat wajah kucing bercerita "ibu guru aku buat kucing, lihat baguskan, kumisnya warna coklat, lalu pisangnya untuk matanya", semua anak sangat antusias saat menunjukkan hasil karyanya.

\section{Pembahasan dan Hasil Penelitian}

Berdasarkan hasil pengamatan yang dilakukan oleh peneliti, kegiatan cooking class dapat berdampak positif pada anak membuat anak berpikir secara estetis, tentang bagaimana keindahan dapat dibuat melalui kegiatan membuat roti isi.

\section{SIMPULAN DAN SARAN}

Dalam mengembangkan sikap estetis pada anak melalui kegiatan cooking class di RA As-Shofa Kabupaten Bandung, guru mengajak anak-anak untuk berkreasi sesuai kemampuannya. Agar anak dapat mengembangkan kemampuan estetika untuk beradaptasi dengan aspek perkembangan lainnya, dan memiliki rasa tanggung jawab dalam memasak, anak dapat dengan sabar memikirkan apa yang telah mereka pelajari di kegiatan cooking class ini. Berdasarkan hasil penelitian RA As-Shofa di Kabupaten Bandung dapat disimpulkan bahwa pengembangan estetika melalui kegiatan cooking class pada anak usia 5-6 tahun yaitu membangun kesadaran diri untuk menunjukkan kemampuan dalam menciptakan estetika dan menyesuaikan dengan tema rasa tanggung jawab anak mulai timbul untuk membuat kreasi makanan yang dibuat serta dapat mengekspresikannya sesuai dengan pencapaian.

Penelitian tentang pengembangan estetika melalui kegiatan cooking class di RA As-Shofa Kabupaten Bandung masih terdapat banyak kekurangan serta jauh dari katakata sempurna maka dari itu peneliti akan melakukan dengan lebih baik lagi dalam penelitian agar dapat memberikan banyak masukan dan motivsi dalam melakukan penelitian.

\section{DAFTAR PUSTAKA}

Abdah, R. (2013). Kegiatan Cooking Class Untuk Meningkatkan Kemampuan Motorik Halus Anak Kelompok B TK SUCCES Kecamatan Rungkut Surabaya.

Anggraheni, I. (2019). Profil Perkembangan Motorik Halus Dan Kreativitas Anak Kelompok B Dalam Kegiatan Cooking Class. Thufuli: Jurnal Ilmiah Pendidikan Islam Anak Usia Dini, 1(1), 46-62. 
Bakhti, W. (2015). Upaya Meningkatkan Entrepreneurship Anak Melalui Cooking Class Pada Kelompok B . Jurnal PG-PAUD Trunojoyo.

Falah, R. F. (2019). Nilai-Nilai Estetika Dalam Penataan Lingkungan Pendidikan Anak Usia Dini DI Kabupaten Kudus. Thufula.

Hasan, B., Thompson, W. G., Almasri, J., Wang, Z., Lakis, S., Prokop, L. J., ... \& Murad, M. H. (2019). The effect of culinary interventions (cooking classes) on dietary intake and behavioral change: a systematic review and evidence map. BMC nutrition, 5(1), 29.

Maulisa, F. (2020). Strategi Kepala Sekolah Dalam Pengembangan Estetika Kelas di TK Alifba I Iskandar Muda Banda Aceh (Doctoral dissertation, Universitas Islam Negeri Ar-Raniry Banda Aceh)

Permendiknas. (2009). Standar Pendidikan Anak Usia Dini. Jakarta.

Pudjawan, K., Juniyanasari, L. P., \& Ujianti, P. R. (2015). Penerapan Pembelajaran Kontekstual Melalui Cooking Class Untuk Meningkatkan Keterapmpilan Motorik Halus Pada Anak. Jurnal Pendidikan Guru Pendidikan Anak Usia Dini.

Rahmawati, A., Juhaeni, J., Aisah, S., Kinasih, A., \& Shibyany, N. (2019). Pengelolaan Kelas Terhadap Siswa Tuna Rungu-Wicara di Kelompok A1 PGRA Mamba'ul Hisan. JECED: Journal of Early Childhood Education and Development, 1(2), 98-103.

Suyanto, S. (2005). Konsep Dasar Pendidikan Anak Usia Dini . Jakarta: Depdiknas.

Syahputri, W. (2021). Pembelajaran Gerak dan Tari Untuk Meningkatkan Estetika Anak Kelompok B di RA Ar-Rasyid Kompleks Sukamaju Indah Blok GG-1 Desa Sukamaju Kecamatan Sunggal Kabupaten Deli Serdang Tahun 2020 (Doctoral dissertation, UMSU).

\section{AUTHOR}

Heri Hidayat, Nadia Nuraziani, Qolbiatum Mutmainah, Silva Inten Sulistya Afiliasi UIN Sunan Gunung Djati Bandung. 